Gut, 1981, 22, 549-553

\title{
Somatostatin, gastrointestinal peptides, and the carcinoid syndrome
}

\author{
R G LONG, ${ }^{*}$ J R PETERS, $\dagger$ S R BLOOM, M R BROWN, W VALE, J E RIVIER, \\ AND D G GRAHAME-SMITH \\ From the Department of Medicine, Hammersmith Hospital, Royal Postgraduate Medical School, London; \\ the MRC Unit and University Department of Clinical Pharmacology, The Radcliffe Infirmary, Oxford, \\ and the Salk Institute, San Diego, California, USA
}

SUMMARY During a control infusion noradrenaline and alcohol each provoked carcinoid flushing in four of five patients and pentagastrin in two of five patients. When tetradecapeptide somatostatin was infused on another day no patient flushed at any time, even when $16 \mu \mathrm{g}$ of either noradrenaline or pentagastrin were administered. Carcinoid flushing was not associated with release of gastrin or any of the other vasoactive or postprandially released gut regulatory peptides measured. In a sixth patient with severe prolonged carcinoid flushing, subcutaneous Des $\mathrm{AA}^{1,2.4,5.12} \mathrm{DTrp}^{8}$ somatostatin markedly reduced the incidence and severity of flushing for two days. Somatostatin is thus a potent inhibitor of carcinoid flushing, but no evidence has been found for the gut hormones measured to be mediators of flushing.

Somatostatin is a 14 aminoacid polypeptide (Fig. 1) which was initially isolated in the hypothalamus as growth hormone release inhibitory hormone ${ }^{1}$ but subsequently has been demonstrated to be present in the $\mathrm{D}$ cell in man throughout the gastrointestinal tract and pancreas and in the $\mathrm{C}$ cell of the thyroid. ${ }^{2}$ Infusion studies have shown that it has widespread effects in inhibiting plasma concentrations of many anterior pituitary, gastrointestinal, and pancreatic hormones and it also causes a reduction in pancreatic, biliary, and gastrointestinal secretions. ${ }^{3}$ In man somatostatin has a half-life of about three minutes ${ }^{4}$ and, in view of its therapeutic potential, attempts have been made to synthesise analogues which are long acting when given subcutaneously. ${ }^{5}$

A recent report in three patients with the carcinoid syndrome suggested that tetradecapeptide somatostatin could prevent stimulated flushing. ${ }^{6}$ As pentagastrin stimulated carcinoid flushing in these patients and plasma gastrin concentrations are known to rise after a meal (a common flush-provoker), it was suggested that gastrin might be a mediator of the

\footnotetext{
*Present address and address for correspondence: Gastrointestinal Laboratory, St Thomas' Hospital, London SE1 7EH.

+Present address: Department of Medicine. Welsh National School of Medicine. University of Wales, Heath Park. Cardiff CF4 4XN.

Received for publication 28 January 1981
}

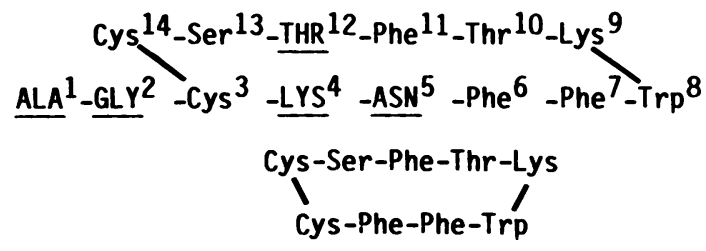

Fig. 1 Aminoacid sequence of regular somatostatin above and Des $A A^{1}$ 1.2.4.5.12 somatostatin below. The tryptophan in position 8 in regular somatostatin was the $D$ epimer in the nonapeptide analogue.

carcinoid flush. The aims of this study were to assess further the effects of somatostatin and pentagastrin on carcinoid flushing, to assess whether gastrin or other postprandially released or vasoactive gastrointestinal peptides were released during carcinoid flushing, and to see if the long-acting nonapeptide analogue Des $\mathrm{AA}^{1}$, 2. 4.5,12 $\mathrm{D}^{\mathrm{T}} \mathrm{rp}^{8}$ somatostatin (Fig. 1) given subcutaneously reduced carcinoid flushing over two days.

\section{Methods}

PATIENTS

Clinical details of the six patients at the time of study are shown in Table 1 . The mean age $( \pm$ SEM) of the five male patients (numbers 1-5) studied 
Table 1 Clinical details of patients studied

\begin{tabular}{|c|c|c|c|c|c|c|}
\hline $\begin{array}{l}\text { Patient } \\
\text { (no.) }\end{array}$ & $\begin{array}{l}\text { Age (vr) } \\
\text { and sex }\end{array}$ & $\begin{array}{l}\text { Site of } \\
\text { primary tumour }\end{array}$ & $\begin{array}{l}\text { Duration of } \\
\text { flushing (yr) }\end{array}$ & Daily medication & $\begin{array}{l}\text { Frequency of } \\
\text { flushing day }{ }^{-1} \\
\text { (on treatment) }\end{array}$ & $\begin{array}{l}\text { Presencel } \\
\text { absence diarrhoea }\end{array}$ \\
\hline 1 & $55: M$ & Ileum & 20 & Indoramine $20 \mathrm{mg}$ tds & 3 & - \\
\hline 2 & $63: M$ & Ileum & 13 & $\begin{array}{l}\text { Digoxin } 0.25 \mathrm{mg} \text {. } \\
\text { frusemide } 40 \mathrm{mg} \text { bd. } \\
\text { spironolactone } 25 \mathrm{mg} \text { tds }\end{array}$ & 4 & - \\
\hline 3 & $61: M$ & Unknown & 5 & $\begin{array}{l}\text { Indoramine } 20 \mathrm{mg} \text { tds. } \\
\text { cimetidine } 200 \mathrm{mg} \text { tds }\end{array}$ & 1 & + \\
\hline 4 & $56: \mathrm{M}$ & Ileum & 4 & Cyproheptadine $4 \mathrm{mg}$ tds & 1 & + \\
\hline 5 & $66: M$ & $\begin{array}{l}\text { Meckel's } \\
\text { diverticulum }\end{array}$ & 2 & $\begin{array}{l}\text { Parachlorophenylalanine } 1 \mathrm{~g} \text { tds. } \\
\text { methysergide } 1 \mathrm{mg} \text { tds }\end{array}$ & 1 & + \\
\hline 6 & $56: F$ & Unknown & 8 & $\begin{array}{l}\text { Cyproheptadine } 24 \mathrm{mg} \text { tds. } \\
\text { methysergide } 1 \mathrm{mg} \text { tds. } \\
\text { cimetidine } 200 \mathrm{mg} \text { tds } \\
\text { chlorpheniramine } 4 \mathrm{mg} \text { tds }\end{array}$ & 3 & + \\
\hline
\end{tabular}

with intravenous tetradecapeptide somatostatin was $60 \pm 2$. Case 6 was studied only with subcutaneous Des $\mathrm{AA}^{1}$. 2. 4. 5. $12 \mathrm{D} \mathrm{Trp}^{8}$ somatostatin. The primary tumour site had been located and excised from the ileum in three patients and from a Meckel's diverticulum in one patient but was unknown in two patients. All six patients had clinical and liver scan evidence of widespread hepatic metastases; in patients 1,3 (on three occasions), and 4, surgery had previously been performed to excise hepatic metastases. All the patients had a long history of carcinoid flushing and all except patient 2 were receiving flush-controlling medication which was stopped 48 hours before the patients were studied. Cases 3-6 passed loose stools two to six times daily. Cases 3, 4, and 6 had clinical evidence of right-sided cardiac involvement. All patients had raised 24 hour urinary 5-hydroxy indole acetic acid concentrations. Ethical permission was obtained for this study from the Oxford Area Health Authority (Teaching) Ethics' Committee and all the patients gave informed written consent.

Cases 1-5 were studied after fasting overnight on two mornings 48 hours apart. A thermistor to monitor continuously skin temperature was attached to the forehead. An intravenous cannula was inserted into an antecubital fossa vein in both arms. Basal blood samples were collected $(-20,-10$, zero minutes). The infusion was started after the zero blood sample: on the first day this contained $0.9 \mathrm{~g} \%$ (w/v) sodium chloride and $2 \mathrm{~g} \%(\mathrm{w} / \mathrm{v})$ human albumin (infusion rate $1.1 \mathrm{ml} / \mathrm{minute}$ ) and on the second study day somatostatin $(70 \mathrm{pmol} / \mathrm{kg} / \mathrm{min})$ was added to the infusate. After 20 minutes' infusion the patients were given serial intravenous bolus injections of noradrenaline (dose range $1 \cdot 0-16 \cdot 0 \mu \mathrm{g} / \mathrm{min}$ ) and pentagastrin (dose range $0.5-16.0 \mu \mathrm{g} / \mathrm{min}$ ) and oral alcohol $(40 \mathrm{ml}$ sherry). If no flush had occurred five minutes after an injection of noradrenaline or pentagastrin, the dose was doubled and the test repeated to a maximum of $16 \mu \mathrm{g}$. A flush was defined as the development of marked cutaneous erythema of the head and neck associated with a rise in skin temperature of at least $0 \cdot 6^{\circ} \mathrm{C}$, a rise in pulse rate of at least 10 per minute, and a fall in systolic blood pressure of at least $10 \mathrm{mmHg}$.

Basal blood samples for plasma glucose and gut peptide measurement were taken before each new substance was given, at the beginning, middle, and end of each flush and, if no flush were induced, three minutes after $16 \mu \mathrm{g}$ of pentagastrin or noradrenaline or the alcohol had been given (it was found that flushing started approximately three minutes after an oral or intravenous stimulus was given). The plasma hormone samples were collected into heparinised tubes containing 400 Kallikrein-inactivating units of aprotinin (Trasylol)/ml blood added, centrifuged immediately, and stored until radioimmunoassay.

Plasma glucose was measured by autoanalyser. Previously described radioimmunoassays were used for the measurement of plasma gastrin, ${ }^{7}$ vasoactive intestinal polypeptide ${ }^{8}$ neurotensin, ${ }^{9}$ pancreatic polypeptide, ${ }^{10}$ motilin, ${ }^{11}$ insulin, ${ }^{12}$ gastric inhibitory polypeptide,$^{13}$ glucagon, and enteroglucagon..$^{14-16}$

Patient 6 was taken off her medication for two days and then assessed for a control day (day 1). At 07.30 on day 2 , she received a test dose of $0.5 \mathrm{mg}$ Des AA 1. 2. 4. 5. 12 D Trp ${ }^{8}$ somatostatin subcutaneously; additional subcutaneous $2 \mathrm{mg}$ injections were given at 09.00 and 21.00 on day 2 and at 09.00 on day 3. Day 4 acted as a second control day. Des AA 1.2.4.5.12 D Trp8 somatostatin was synthesised by the solid phase method. ${ }^{17}$

\section{Results}

The flushing response to the three different provoking agents used is shown in Table 2. Four of the five patients each flushed to intravenous noradrenaline and to oral alcohol. Case 5 developed marked hyperventilation, pallor, and a rise in systolic blood pressure of $25 \mathrm{mmHg}$ but did not flush when given 
Table 2 Flushing response to three different stimuli of five patients studied on control and somatostatin infusion days

\begin{tabular}{|c|c|c|c|c|c|c|}
\hline \multirow[t]{2}{*}{ Patient (no.) } & \multicolumn{2}{|c|}{ Intravenous noradrenaline } & \multicolumn{2}{|c|}{ Intravenous pentagastrin } & \multicolumn{2}{|c|}{ Oral alcohol } \\
\hline & $\begin{array}{l}\text { Control } \\
(\mu g)\end{array}$ & $\begin{array}{l}\text { Somatostatin } \\
(\mu g)\end{array}$ & $\begin{array}{l}\text { Control } \\
(\mu g)\end{array}$ & $\begin{array}{l}\text { Somatostatin } \\
(\mu \mathrm{g})\end{array}$ & $\begin{array}{l}\text { Control } \\
(\mathrm{ml})\end{array}$ & $\begin{array}{l}\text { Somatostati } \\
(\mathrm{ml})\end{array}$ \\
\hline 1 & $1 \cdot 0$ & $(16 \cdot 0)$ & $(16 \cdot 0)$ & $(16 \cdot 0)$ & 40 & (40) \\
\hline 2 & 1.0 & $(16 \cdot 0)$ & 0.5 & $(16.0)$ & 40 & (40) \\
\hline 3 & $4 \cdot 0$ & $(16 \cdot 0)$ & $16 \cdot 0$ & $(16.0)$ & 40 & (40) \\
\hline 4 & $2 \cdot 0$ & $(16.0)$ & $(16 \cdot 0)$ & $(16.0)$ & (40) & (40) \\
\hline 5 & $(16 \cdot 0)$ & $(16 \cdot 0)$ & $(16 \cdot 0)$ & $(16 \cdot 0)$ & 40 & (40) \\
\hline
\end{tabular}

The lowest dose is indicated at which an incremental stimulus provoked a flush; doses in parentheses indicate the highest incremental dose used at which flushing did not occur.

$16 \mu \mathrm{g}$ noradrenaline. Pentagastrin provoked flushing in only two patients and the four patients who received $16 \mu \mathrm{g}$ all developed transient systemic symptoms including malaise, nausea, and headache at this dose.

When somatostatin was infused, none of the five patients flushed to any of the incremental stimuli, including boluses of noradrenaline and pentagastrin $16 \mu \mathrm{g}$ (Table 2). The somatostatin did not prevent the systemic effects of the larger doses of noradrenaline or pentagastrin. When somatostatin was infused none of the patients had any abnormal symptoms and no significant change in blood pressure or pulse occurred. In patient 2 , withdrawal of somatostatin was associated with a mild flush lasting eight minutes.

Fasting plasma glucose and gut peptide concentrations are shown in Table 3 and are all within the normal range. Plasma glucose and peptide concentrations did not change at any time during the provoked flushing attacks on the control infusion day. During the somatostatin infusions the mean concentrations of all fell.

The response of case 6 to subcutaneous Des $\mathrm{AA}^{1}$, 2, 4, 5, 12 D Trp ${ }^{8}$ somatostatin is shown in Fig. 2. Severe prolonged spontaneous facial, trunk, and limb flushing with lacrimation occurred on the control days 1 and 4 . When the nonapeptide somatostatin analogue was given on days 2 and 3 , the severity and duration of flushing were much reduced with facial involvement only and lacrimation disappeared. The patient experienced no side-effects and the nonapeptide somatostatin analogue appeared superior in this short-term study to her previous oral quadruple therapy (Table 1).

\section{Discussion}

This study confirms the previous observation that intravenous tetradecapeptide somatostatin is a highly effective inhibitor of pentagastrin induced carcinoid flushing. ${ }^{6}$ In addition it has been demonstrated that somatostatin also inhibits spontaneous flushing and flushing induced by noradrenaline and alcohol. No side effects were seen apart from one patient who had a mild episode of 'rebound' flushing on stopping the infusion. In another unreported patient we have observed a major 'rebound' effect with diarrhoea, asthma, and prostration for 30 minutes. Davis et al. have reported a patient with the carcinoid syndrome whose secretory diarrhoea and small intestinal water, chloride, and sodium absorption improved during a 48 hour intravenous somatostatin infusion. ${ }^{18}$ The study using the subcutaneous nonapeptide somatostatin analogue shows that this analogue also helps unprovoked flushing. Somatostatin may thus have a future role as a symptomatic treatment for several aspects of the carcinoid syndrome.

The provocation of carcinoid flushing by numerous

Table 3 Plasma concentrations (mean $\pm S E M$ ) of glucose and gut peptides before infusion, during flushing attacks, and one hour after starting somatostatin infusion

\begin{tabular}{|c|c|c|c|c|}
\hline & \multicolumn{2}{|c|}{ Before infusion } & \multirow{2}{*}{$\begin{array}{l}\text { During } \\
\text { flushing }\end{array}$} & \multirow{2}{*}{$\begin{array}{l}\text { One hour } \\
\text { after starting } \\
\text { somatostatin } \\
\text { infusion }\end{array}$} \\
\hline & $\begin{array}{l}\text { Control } \\
\text { day }\end{array}$ & $\begin{array}{l}\text { Somatostatin } \\
\text { day }\end{array}$ & & \\
\hline Glucose (mmol/l) & $4 \cdot 0 \pm 0 \cdot 4$ & $4 \cdot 1 \pm 0 \cdot 4$ & $3 \cdot 8 \pm 0 \cdot 4$ & $3 \cdot 0 \pm 0 \cdot 3$ \\
\hline Gastrin (pmol/l) & $10 \cdot 8 \pm 3 \cdot 4$ & $12 \cdot 0 \pm 4 \cdot 2$ & $11 \cdot 8 \pm 4 \cdot 3$ & $6 \cdot 6 \pm 3 \cdot 3$ \\
\hline Vasoactive intestinal polypeptide ( $\mathrm{pmol} / \mathrm{l})$ & $8 \cdot 8 \pm 3 \cdot 1$ & $9 \cdot 0 \pm 2 \cdot 9$ & $9 \cdot 6 \pm 3 \cdot 5$ & $7 \cdot 0 \pm 3 \cdot 0$ \\
\hline Neurotensin $(\mathrm{pmol} / \mathrm{l})$ & $46 \cdot 2 \pm 5 \cdot 9$ & $48 \cdot 8 \pm 7 \cdot 5$ & $45 \cdot 2 \pm 8 \cdot 6$ & $30 \cdot 4 \pm 5 \cdot 7$ \\
\hline Pancreatic polypeptide (pmol/1) & $80 \cdot 4 \pm 39 \cdot 4$ & $88 \cdot 4 \pm 57 \cdot 0$ & $93 \cdot 8 \pm 54 \cdot 3$ & $24 \cdot 4 \pm 7 \cdot 0$ \\
\hline Motilin (pmol/l) & $35 \cdot 0 \pm 5 \cdot 5$ & $32 \cdot 8 \pm 7 \cdot 4$ & $33 \cdot 4 \pm 5 \cdot 0$ & $4 \cdot 2 \pm 1 \cdot 4$ \\
\hline Insulin (pmol/l) & $53 \cdot 2 \pm 20 \cdot 1$ & $57 \cdot 4 \pm 15 \cdot 3$ & $46 \cdot 6 \pm 19 \cdot 4$ & $2 \cdot 4 \pm 0 \cdot 4$ \\
\hline Gastric inhibitory polypeptide (pmol/l) & $10 \cdot 0 \pm 1 \cdot 5$ & $11 \cdot 0 \pm 1 \cdot 3$ & $11 \cdot 6 \pm 1 \cdot 9$ & $8 \cdot 0 \pm 1 \cdot 5$ \\
\hline Glucagon (pmol/1) & $14 \cdot 8 \pm 3 \cdot 3$ & $16 \cdot 8 \pm 5 \cdot 6$ & $16 \cdot 2 \pm 3 \cdot 2$ & $5 \cdot 2 \pm 2 \cdot 6$ \\
\hline Enteroglucagon (pmol/l) & $39 \cdot 4 \pm 12 \cdot 2$ & $47 \cdot 0 \pm 9 \cdot 4$ & $47 \cdot 0 \pm 12 \cdot 9$ & $21 \cdot 8 \pm 5 \cdot 2$ \\
\hline
\end{tabular}




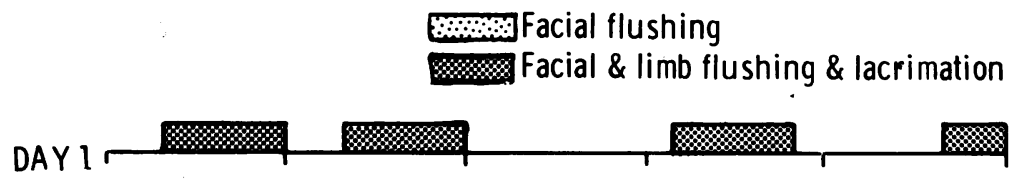

Fig. 2 Flushing response in patient 6 on control days 1 and 4 and on days 2 and 3 when Des $A A^{1.2,4.5,12}$ D Trp ${ }^{8}$ somatostatin (arrows) was administered subcutaneously. On the treatment days lacrimation disappeared and the duration and severity of flushing were much reduced.
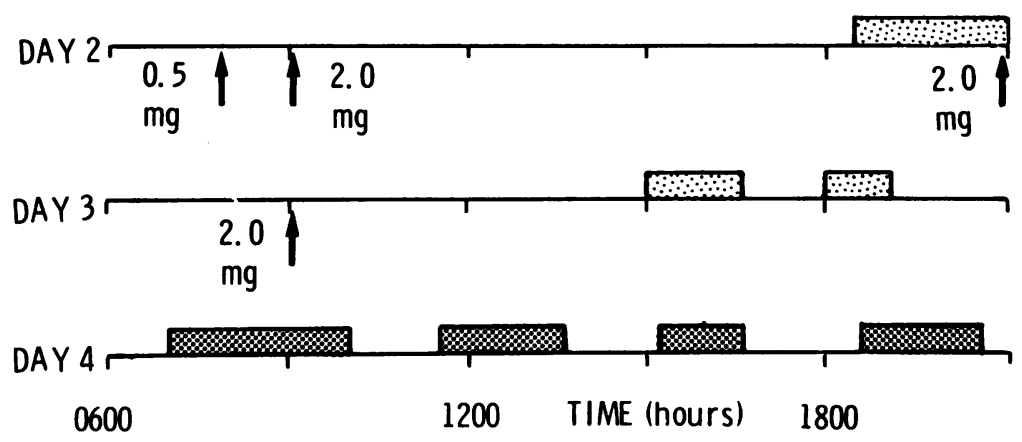

factors has long been recognised. ${ }^{19}$ In this study only two of the five patients tested flushed to pentagastrin and only case 2 did so in the absence of systemic pentagastrin-induced symptoms. No changes in plasma gastrin concentrations were seen during any flushing attacks. Frölich et al. did not measure plasma gastrin concentrations and two of their three cases only flushed with $16 \mu \mathrm{g}$ pentagastrin boluses. ${ }^{6}$ Overall, then, their suggestion that gastrin is a natural mediator of carcinoid flushing seemed dubious.

It has been suggested that tumour kallikrein release with subsequent bradykinin formation may be the humoral mechanism of carcinoid flushing but the case is not proven..$^{20}$ In some patients with gastric carcinoids histamine may have a role to play in the production of the 'geographical' flushing and a combination of $\mathrm{H} 1$ and $\mathrm{H} 2$ blocking agents may be effective in these patients. ${ }^{21} \mathrm{~A}$ number of peptides including pancreatic polypeptide, neurotensin, enteroglucagon, motilin, and substance $P$ have been demonstrated to be present in carcinoid tumours. Infusion studies have shown that vasoactive intestinal polypeptide, neurotensin, and substance $P$ are vasoactive peptides and gastric inhibitory polypeptide, pancreatic polypeptide, neurotensin, enteroglucagon, motilin, insulin, and pancreatic glucagon are all released after a meal. ${ }^{3}$ It therefore seemed possible that one or more of these peptides might be flush provokers or mediators. This study has provided no evidence for this hypothesis but clearly demonstrates that some part of the presumed biochemical cascade of carcinoid flushing is somatostatin sensitive, and, from the spectrum of its effects, it seems quite likely that somatostatin is preventing the release of pharmacologically active materials from the tumour cell, whatever the provoking agent.

The search for long-acting and specific somatostatin analogues continues. This study shows that subcutaneous Des AA $1,2,4,5,12$ D Trp $^{8}$ somatostatin has a prolonged duration of action in preventing carcinoid flushing without side-effects. The prolonged duration of action presumably occurs because of slow release of the hydrophobic molecule from subcutaneous tissues. An effective subcutaneous injection given once or twice daily has obvious advantages over continuous intravenous infusion. Somatostatin and its analogues might be particularly useful for the treatment of carcinoid 'crises' and during surgery to prevent the severe bronchoconstriction and hypotension which may occur.

We are grateful to the Lister Institute, Elstree, Herts. for the kind gift of $10 \%$ human albumin and to the Medical Research Council for financial support of Dr R G Long as a Training Fellow.

\section{References}

'Brazeau P, Guillemin R. Somatostatin: newcomer from the hypothalamus. N Engl J Med 1974; 290: 963-4.

${ }^{2}$ Polak JM, Pearse AGE, Grimelius L, Bloom SR, Arimura A. Growth-hormone release-inhibiting hormone in gastrointestinal and pancreatic D cells. Lancet 1975; 1: 1220-2. ${ }^{3}$ Bloom SR, Polak JM. Gut hormones. Adv Clin Chem 1980: 21: 177-244.

${ }^{4}$ Sheppard M, Shapiro B, Pimstone B, Kronheim S, Berelowitz M, Gregory M. Metabolic clearance and plasma 
half-disappearance time of exogenous somatostatin in man. $J$ Clin Endocrinol Metab 1979; 48: 50-3.

${ }^{5}$ Long RG, Barnes AJ, Adrian TE, et al. Suppression of pancreatic endocrine tumour secretion by long-acting somatostatin analogue in man. Lancet 1979; 2: 764-7.

${ }^{6}$ Frölich JC, Bloomgarden ZT, Oates JA, McGuigan JE, Rabinowitz D. The carcinoid flush: provocation by pentagastrin and inhibition by somatostatin. N Engl J Med 1978; 299: 1055-7.

${ }^{7}$ Russell RCG, Bloom SR, Fielding CP, Bryant MG. Current problems in the measurement of gastrin release. Postgrad Med J 1976; 52: 645-50.

${ }^{8}$ Mitchell SJ, Bloom SR. Measurement of fasting and postprandial VIP in man. Gut 1978; 19: 1043-8.

${ }^{9}$ Blackburn AM, Bloom SR. Radioimmunoassay for neurotensin in human plasma. J Endocrinol 1979; 83: 175-81.

${ }^{10} \mathrm{Björnsson} \mathrm{OG}$, Adrian TE, Dawson J, et al. Effects of gastrointestinal hormones on fasting gallbladder storage patterns in man. Eur J Clin Invest 1979; 9: 293-300.

"Christofides ND, Modlin IM, Fitzpatrick ML, Bloom SR. Effect of motilin on the rate of gastric emptying and gut hormone release during breakfast. Gastroenterology 1979; 76: 903-7.

${ }^{12}$ Albano JD, Ekins RP, Maritz G, Turner RC. A sensitive, precise radioimmunoassay of serum insulin relying on charcoal separation of bound and free hormone moieties. Acta Endocrinol 1972; 70; 487-509.

${ }^{13}$ Sarson DL, Bryant MG, Bloom SR. A radioimmunoassay of gastric inhibitory polypeptide in plasma. $J$ Endocrinol 1980; 85: 487-96.

${ }^{14}$ Alford FB, Bloom SR, Nabarro JDN. Glucagon levels in normal and diabetic subjects: use of a specific immunoabsorbant for glucagon radioimmunoassay. Diabetologia 1977; 13: 1-6.

${ }^{15}$ Thompson JPS, Bloom SR. Plasma enteroglucagon and plasma volume change after gastric surgery. Clin Sci Mol Med 1976; 51: 177-183.

${ }^{16}$ Long RG, Albuquerque.RH, Bloom SR, et al. Response of plasma pancreatic and gastrointestinal hormones and growth hormone to oral and intravenous glucose and insulin hypoglycaemia in Chagas's disease. Gut 1980; 21 : 772-777.

${ }^{17}$ Rivier JE. Total solid phase synthesis. J Am Chem Soc 1974; 96: 2986-92.

${ }^{18}$ Davis GR, Camp RC, Raskin P, Krejs GJ. Effect of somatostatin infusion on jejunal water and electrolyte transport in a patient with secretory diarrhoea due to malignant carcinoid syndrome. Gastroenterology 1980; 78: 346-9.

${ }^{19}$ Robertson JIS, Peart WS, Andrews TM. The mechanism of facial flushes in the carcinoid syndrome. $Q J \mathrm{Med} 1962$; 21: 103-23.

${ }^{20} \mathrm{Grahame-Smith} \mathrm{DG.} \mathrm{The} \mathrm{carcinoid} \mathrm{syndrome.} \mathrm{London:}$ Heinemann Medical Books, 1972.

${ }^{21}$ Roberts LJ, Marney SR, Oates JA. Blockade of the flush associated with metastatic gastric carcinoid by combined $\mathrm{H}_{1}$ and $\mathrm{H}_{2}$ receptor antagonists. $N$ Engl J Med 1979; 300: 236-8. 